F. med. Genet. (1965). 2, 205.

\title{
Ovarian Dysgenesis and Presumed Isochromosome of the Long Arm of $\mathrm{X}$
}

\author{
MICHAEL J. REE
}

General Practitioner, Keynsham, Somerset

Turner's syndrome has long been associated with primary amenorrhoea, webbing of the neck, cubitus valgus, and short stature (Turner, 1938). The majority of these cases are chromatin negative and have an XO chromosome complement. Ovarian maldevelopment is frequently a feature of this condition (Albright, Smith, and Fraser, 1942), as is the presence of multiple somatic abnormalities. Chromatin positive cases have been reported (De la Chapelle, 1962; Lindsten, 1963; Williams, Engel, and Forbes, 1964) bearing some of the features of the classical Turner's syndrome. Stunting of stature is nearly always evident, but webbing of the neck and other somatic abnormalities are less commonly found. Most of these subjects have been shown to be chromosomal mosaics $\mathrm{XO} / \mathrm{XX}$. A much rarer group is thought to be associated with an $\mathrm{X}$ iso $\mathrm{X}$ chromosome complement.

The isochromosome is metacentric and may be formed by replication of the long arm of the $X$ chromosome. The exact mechanism is not known though there are several theories (Jacobs, Harnden, Buckton, Court Brown, King, McBride, MacGregor, and Maclean, 196I; Lindsten, Fraccaro, Ikkos, Kaijser, Klinger, and Luft, 1963). The latter authors suggest that the isochromosome may result from a misdivision of the centromere which divides transversely instead of longitudinally. They postulate that this is more likely to happen at the first reduction division of meiosis in spermatogonia owing to the possible difficulties in pairing up the morphologically dissimilar $\mathrm{X}$ and $\mathrm{Y}$ chromosomes.

Published material records 16 cases of $X$ iso $X$ chromosome complement in which there was no evidence of mosaicism (Jacobs et al., 1961, Hamerton, Jagiello, and Kirman, 1962; Forbes and Engel, 1963; Lindsten et al., 1963; Lindsten, 1963; Sparkes and Molutsky, 1963; Williams et al., 1964). This paper records two further cases of primary ovarian failure due to presumed isochromosome of the long arm of $X$.

Received March 22, 1965.

\section{Case Reports}

Case I. The second child of unrelated parents born in November 1948, birthweight $6 \frac{1}{2} \mathrm{lb}$. $(2 \cdot 9 \mathrm{~kg}$.), was first seen by me in February 1964. Although a scanty menstrual discharge had occurred some six months previously a regular cycle had never been established. Her mother was 37 and her father 4I years old when she was born. She had a brother who was three years her senior. Both parents and her brother were phenotypically normal. Her mother's height was $5 \mathrm{ft}$. 5 in. (I65 cm.), and her father's height was $6 \mathrm{ft}$. $(183 \mathrm{~cm}$.). Her brother was $6 \mathrm{ft} .2$ in. ( $188 \mathrm{~cm}$.).

Detailed inquiry into the maternal and paternal family history revealed no evidence of thyroid disease or diabetes mellitus. Her father suffered from intermittent claudication and on one occasion his serum cholesterol level had been $305 \mathrm{mg}$./100 ml. Both his parents were stated to have died from coronary thrombosis, as did his eldest brother at the age of 50 years.

The patient (Fig. I) was short ( $4 \mathrm{ft} .8 \frac{3}{4}$ in. $(144.2 \mathrm{~cm}$.))

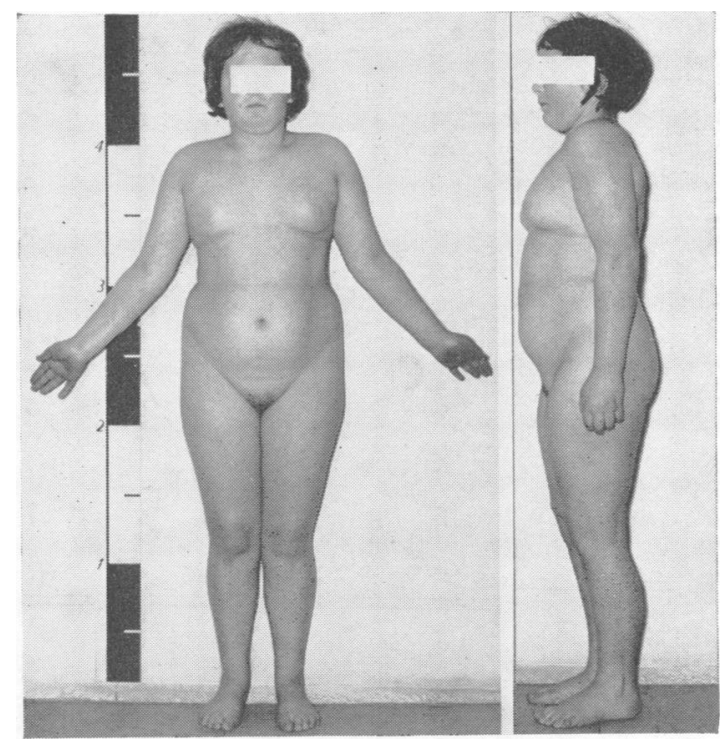

Fig. I. The patient aged 15. Note diminutive stature, short neck, cubitus valgus, and scanty pubic hair. 


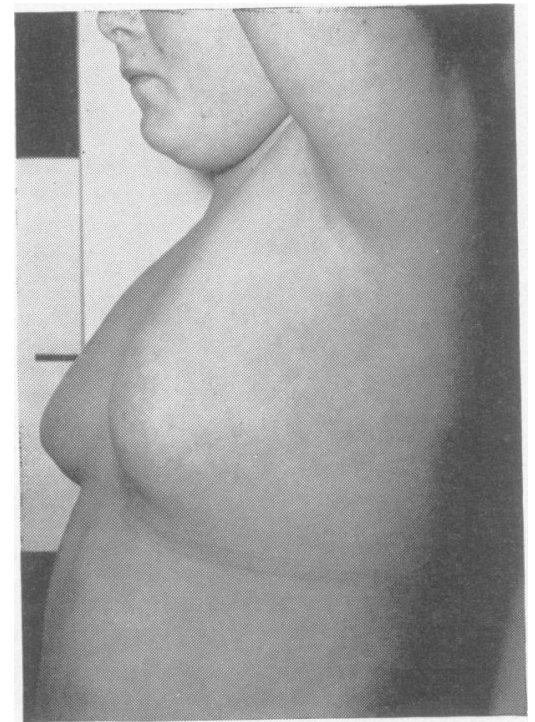

FIG. 2. Photograph demonstrating normal breast contour, infantile nipples, and absent axillary hair. Some pigmented naevi are evident.

and rather obese. The neck was short but there was no webbing. The external genitalia was infantile: the labia majora and clitoris were absent, and the labia minora was very poorly developed. Vaginal examination was not possible but a probe could be passed for a distance of I in. $(2.54 \mathrm{~cm}$.) into the poorly developed vagina. On rectal examination a small uterus was palpable. There was some scanty pubic hair but no axillary hair. The lower jaw tended to recede, and the palate was high and arched. There were multiple pigmented naevi particularly evident on the face. The breast contour was normal, and there was slight pigmentation of the areolar, but Montgomery's tubercles were absent. The nipples (Fig. 2) were poorly-developed infantile struc-

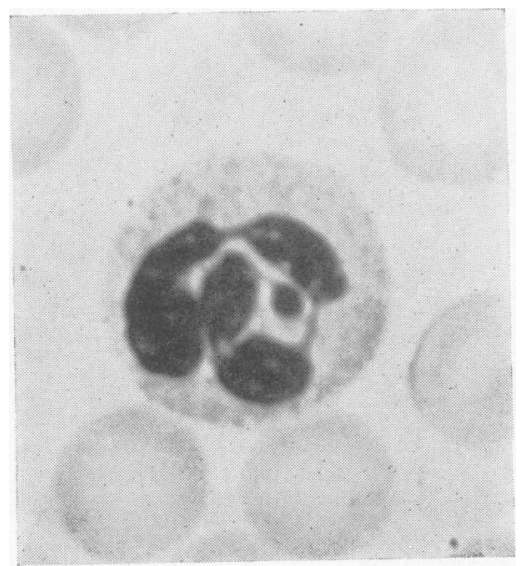

FIG. 3. Neutrophil polymorph with large drumstick. ( $\times$ I500.) tures. There was a well-marked cubitus valgus. Theत fingers were rather short, but the nail development was normal. A transverse palmar crease was present on the left: hand but not on the right. No evidence of colour blind $-\overrightarrow{\bar{c}}$ ness was found (Ishihara plates) and the visual acuity in both eyes was $6 / 12$. The visual fields were normal. Both femoral pulses were palpable. The blood pressure was $145 / 85 \mathrm{~mm}$. Hg. The electrocardiogram was normal.

Intelligence was apparently average. She attended Secondary Modern School and was in a 'C' stream. Im a recent terminal examination she was placed 5 th in a class of 29 children. In certain subjects she was reported to be above average ability.

RADIOGRAPHIC AND LABORATORY INVESTIGATIONS Radiographs of the hands, wrists, and knees showe epiphysial development to be within normal limits? The skull and sella turcica were normal.

Fifty oral cells were examined from buccal smears $54 \%$ of which showed a single nuclear sex chromatin mass. Examination of stained neutrophil leucocytes was made for nuclear appendages. 400 cells were counted of which 64 (16\%) contained 'large drumsticks (Fig. 3) and 69 (17\%) contained 'small clubs'.

The 24-hour urinary excretion of I7-Qxosteroids and I7-hydroxycorticosteroids was $4.75 \mathrm{mg}$. and $8.85 \mathrm{mg}$.ब하 respectively. Serum protein electrophoresis showed \& normal pattern. The serum sodium, potassium, chloride calcium, and inorganic phosphorus levels were withiro normal limits, as was the blood urea. The serum ajaline phosphatase was 19 King Armstrong units (norma\$ range 2-12 units per $100 \mathrm{ml}$.). The serum cholestefot content estimated on two occasions was $260 \mathrm{mg}$./ $100 \mathrm{~m}$ and $263 \mathrm{mg}$./100 ml., respectively. Repeated estima@ tions of blood sugar levels ranged between $65 \mathrm{mg}$. anक्ष $80 \mathrm{mg} . / 100 \mathrm{ml}$. , and routine analysis of the urine revealed no abnormality. The haemoglobin content total white cell count, and differential count weræ normal, and haemoglobin electrophoresis showe normal adult type haemoglobin.

Dr. Ruth Sanger examined samples of blood from the subject and her parents for the sex-linked $\mathbf{X g}^{\mathrm{a}}$ bloo $\overline{\mathrm{\Phi}}$ group. All were $\mathrm{Xg}(\mathrm{a}+)$. The erythrocyte glucose $\frac{8}{8}$ phosphate dehydrogenase (G6PD) activity was 240 units $/ \mathrm{ml}$. of red cell mass.

No thyroid auto-antibodies could be detected in the subject's serum or in that of her parents using the latex particle technique, but a weak positive titre (I/25) was found when the subject's serum was examined bs the tanned red cell haemagglutination test. The 4-houg uptake of 25 microcuries of ${ }^{131}$ I was $35 \%$ of the dose and the 48-hour uptake was $52 \%$. The 48-hour proteion bound iodine (PBI) was $0.7 \%$ of the dose per litre of plasma. (Normal range 0.03 to $0.3 \%$ of the dose pe्f litre of plasma.)

Chromosome Studies. This work together with the autoradiographic findings was undertaken by $\mathrm{Dr}$. $\mathrm{F}_{\mathrm{D}}$ Lewis of Southmead Hospital, Bristol. The chromosomal pattern was studied on growing cells of the peri? 


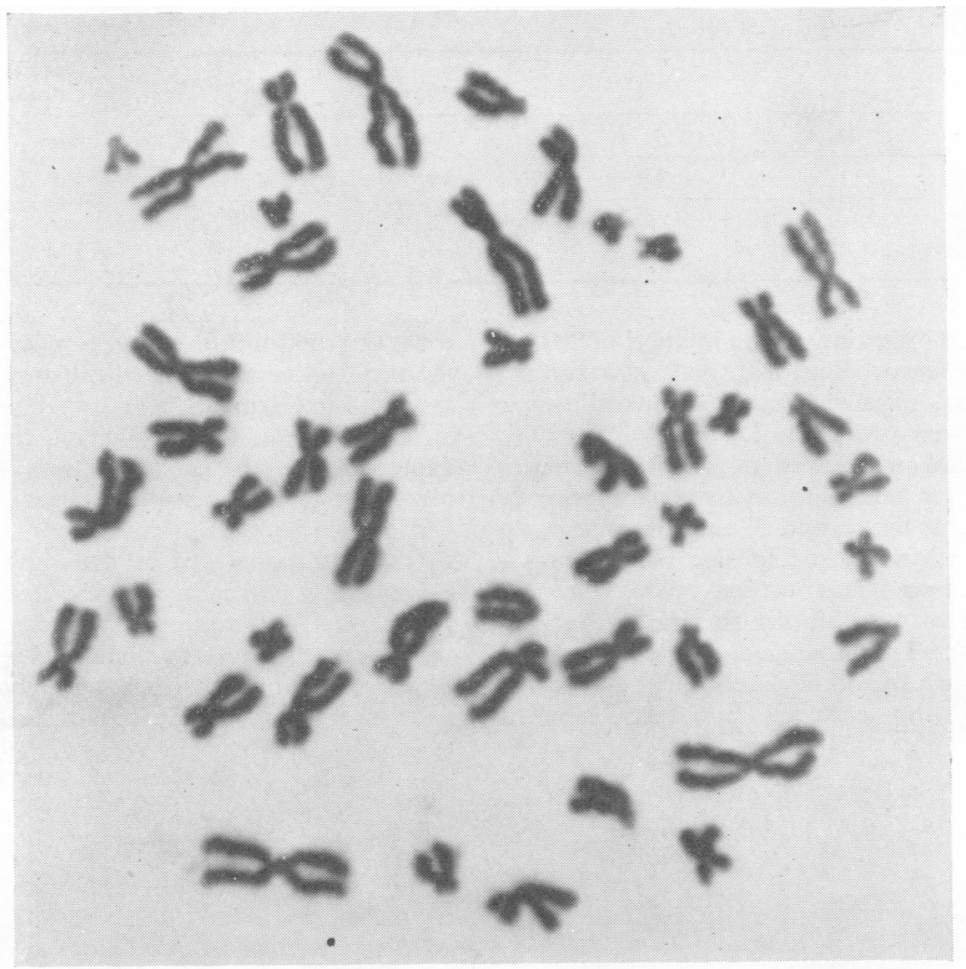

(a)

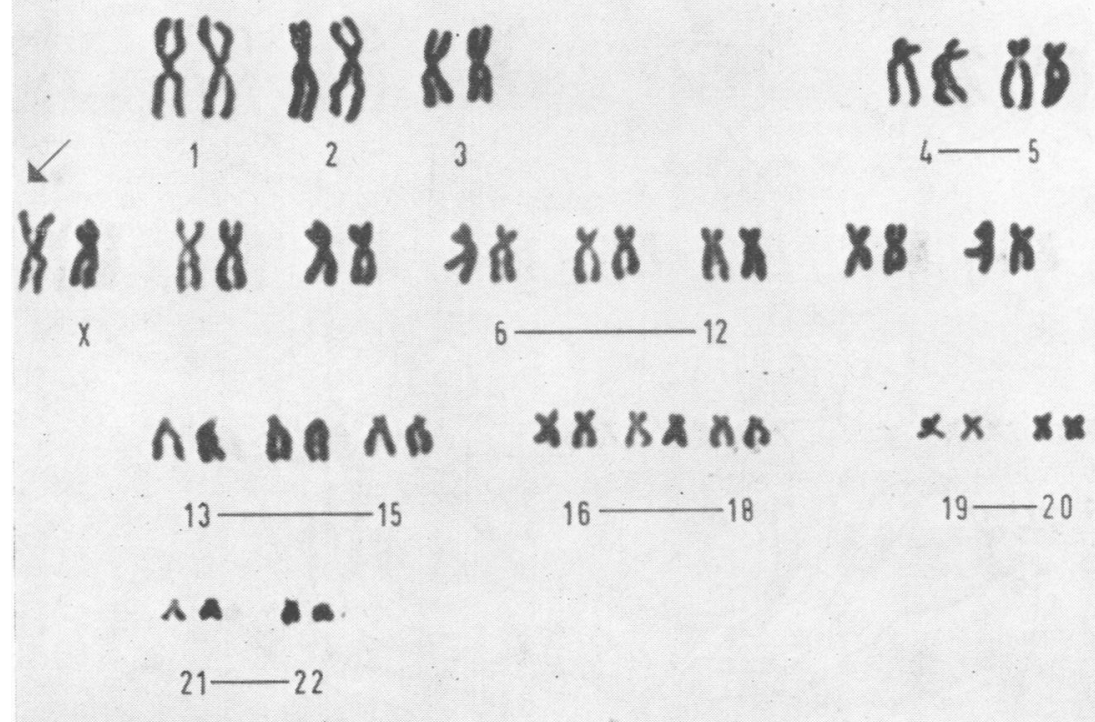

(b)

FIG. 4. A cell in metaphase with karyotype. The isochromosome is indicated by an arrow. 
TABLE I

\begin{tabular}{|c|c|c|c|c|c|c|c|c|c|c|c|c|c|}
\hline \multirow[b]{2}{*}{ No. of chromosomes } & \multicolumn{6}{|c|}{ Subject } & \multicolumn{3}{|c|}{ Mother } & \multicolumn{4}{|c|}{ Father } \\
\hline & 42 & 43 & 44 & 45 & 46 & Total & 45 & 46 & Total & 44 & 45 & 46 & Total \\
\hline Cells counted & $\mathbf{I}$ & - & $\mathbf{I}$ & 一 & 28 & 30 & 4 & 26 & 30 & $\mathbf{I}$ & - & 29 & 30 \\
\hline $\begin{array}{l}\text { Number of oral cells } \\
\text { Percentage having Barr body }\end{array}$ & \multicolumn{6}{|c|}{50} & \multicolumn{3}{|c|}{50} & \multicolumn{4}{|c|}{ so } \\
\hline
\end{tabular}

pheral blood by a modification of the method of Moorhead, Nowell, Mellman, Battipps, and Hungerford (1960). The results, together with the buccal smear analysis, are summarized in Table I.

Subject. The modal cell showed 22 pairs of autosomes and an abnormal sex chromosome in all the spreads examined. In place of the second $\mathrm{X}$ chromosome was a large chromosome which paired in size with chromosome number 3 (Denver Classification, 1960). The two apparently equal arms were similar in size to the long arm of the other $X$. This abnormal chromosome was present also in the two hypomodal cells (Fig. 4). Autoradiographic studies on cultured leucocytes labelled

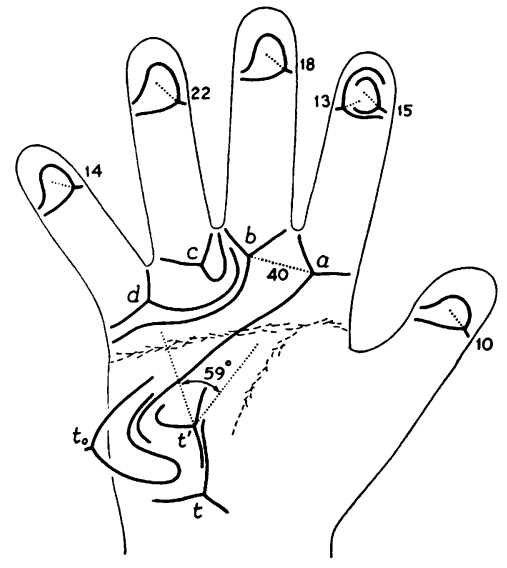

(a)

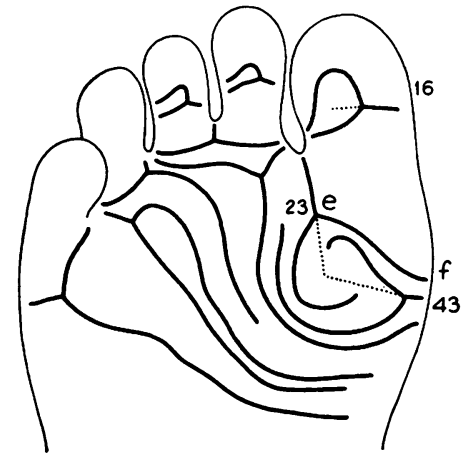

(b)

Fig. 5. Main lines of dermal ridge patterns on finger-tips, palms, and soles.

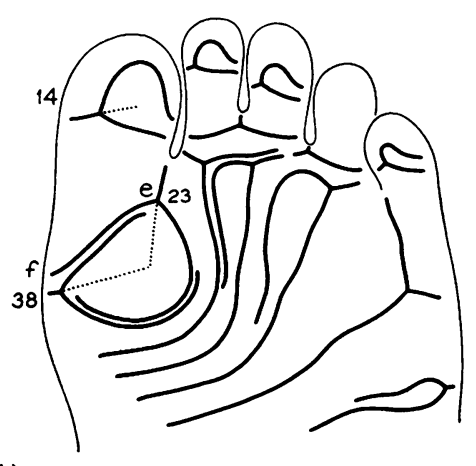

with H.3 thymidine in the S phase of DNA synthesis (Muldal, Gilbert, Lajtha, Lindsten, Rowley, and Fraccaro, 1963; Giannelli, 1963) were performed on 20 cell in which one heavily labelled chromosome could te demonstrated. In each case this was morphologicala consistent with a presumptive isochromosome of $\mathrm{X}$.

Mother. 30 cells in metaphase were examined and I3 cells fully analysed by photography. There was significant abnormality in the cells fully analysed.

Father. A sample of 30 cells in metaphase wăg examined. Of these 29 contained 46 chromosomes, the karyotype being consistent with the normal male of 22 pairs of autosomes and sex chromosomes $\mathrm{X}$ and $\mathrm{Y}$.

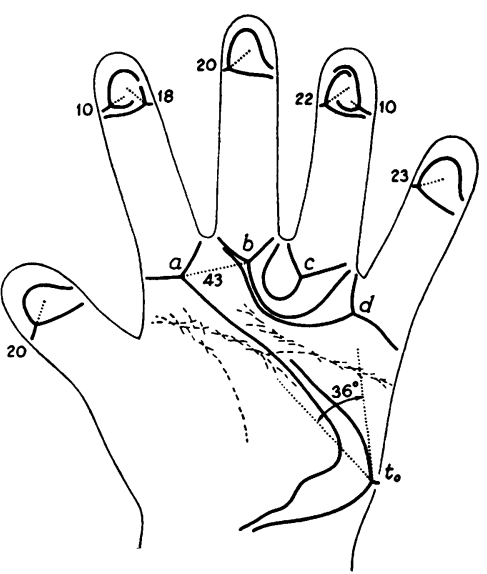


DeRmatoglyphic ANALYsis. Dermatoglyphic patterns (Fig. 5) were examined by Prof. L. S. Penrose of The Galton Laboratory, University College, London. Finger-tip patterns show fairly high intensity. The total ridge count (that is the sum of the highest count on each finger) was I82. Comparison with counts obtained on the average for Turner's syndrome and related conditions, and for normal female controls is shown in Table II where measurements on the palms are also given. There were strong hallucal patterns on the feet, which were of the normal type.

\section{TABLE II}

\begin{tabular}{|c|c|c|c|}
\hline & $\begin{array}{c}\text { Total Ridge } \\
\text { Count (right } \\
\text { and left) }\end{array}$ & $\begin{array}{c}\text { a-b Ridge } \\
\text { Count (right } \\
\text { and left) }\end{array}$ & $\begin{array}{l}\text { Maximal atd } \\
\text { Angle (right } \\
\text { and left) }\end{array}$ \\
\hline Subject & 182 & 83 & $95^{\circ}$ \\
\hline $\begin{array}{l}\text { Turner's syndrome and } \\
\text { related conditions }\end{array}$ & 167 & 96 & $107^{\circ}$ \\
\hline Female controls & 130 & 84 & $88^{\circ}$ \\
\hline
\end{tabular}

TREATMENT. Intermittent treatment with $0.01 \mathrm{mg}$. ethinyl oestradiol per day resulted in withdrawal bleeds which simulated a normal menstrual flow. As yet there has been no improvement in the development of the external genitalia.

Case 2. This patient was seen in April 1964, at the age of 30, by Mrs. M. Bennett at Southmead Hospital, Bristol, for investigation of amenorrhoea. Some I7 years previously three or four scanty periods had occurred. Most of her life had been spent abroad, and she had received, on occasions, various forms of medication with resultant withdrawal bleeding. She had two brothers aged 45 and 33 years, and two sisters 36 and 34 years old, respectively.

The patient was of dimunitive stature (Fig. 6), height $4 \mathrm{ft} .7 \frac{1}{2}$ in. (I4I cm.), and weighed $5 \mathrm{st}$. I I lb. $(36 \cdot 8 \mathrm{~kg}$.). There was a wide carrying angle of the arm. There was no axillary hair but some pubic hair of pubertal distribution. Some pigmented naevi were present on the skin of her chest and face. The breasts were reasonably well developed, but the nipples were infantile in appearance. The labia were poorly developed and the vagina was small. Examination under anaesthetic revealed a small atrophic uterus from which no curettings could be obtained. The ovaries were not palpable. The cardiovascular system was normal and the blood pressure was I30/70 mm. Hg.

RADIOGRAPHIC AND LABORATORY INVESTIGATIONS. Radiography showed a normal sella turcica. Epiphyses in the wrist were fused. The pelvis was normal as was a chest radiograph. Gynaecography failed to reveal ovarian shadows.

Vaginal smears showed that $90 \%$ of the cells had large well-formed nuclei, and 10\% showed a variable degree of pyknosis.

The haemoglobin was 13.9 g./ $100 \mathrm{ml}$. (94\%). Routine urinalysis was normal. The urinary 17-oxosteroid excretion was $6.4 \mathrm{mg}$. $/ 24$ hours, and the I7-hydroxycorticosteroid excretion was $6.8 \mathrm{mg}$. $/ 24$ hours. The urinary 24 -hour excretion of creatinine was $0.8 \mathrm{~g}$.

Chromosome Studies. Chromosomal analysis (Dr. F. Lewis) was performed on cultured leucocytes. The patient had a modal cell line of 46 chromosomes, comprising 22 pairs of autosomes, a single $\mathrm{X}$ chromosome, and a large medial chromosome resembling an isochromosome of the long arm of $\mathrm{X}$.

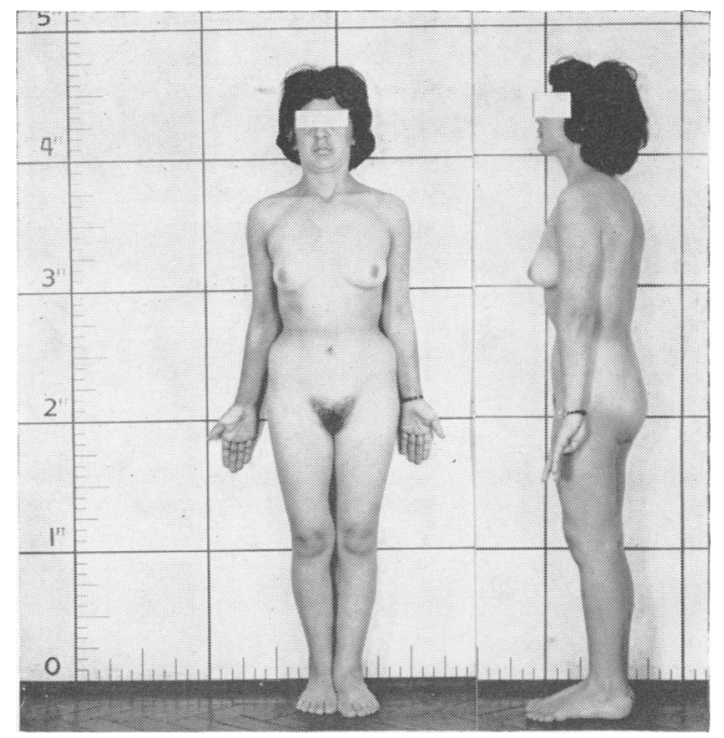

FIG. 6. The second patient aged 28. Short stature, cubitus valgus, and multiple pigmented naevi are evident.

\section{Discussion and Conclusions}

The two patients described show the same clinical features as subjects with a presumed isochromosome of the long arm of $\mathrm{X}$ described by previous authors. Stunting of stature is invariable, as is sexual infantilism. The majority of cases so far reported may be classified with the type of ovarian dysgenesis, without webbing of the neck, and of small stature, as suggested by Polani (196I), but a patient described by Hamerton et al. (I962) was a low-grade mental defective, had severe somatic abnormalities, and had webbing of the neck.

In view of the report by Forbes and Engel (1963) on the high incidence of diabetes mellitus in patients with gonadal dysgenesis and in their close relatives, particular care was taken to find evidence of diabetes mellitus in the paternal and maternal relatives of the first subject; with negative results. Repeated examinations for sugar content were made on 
samples of urine and blood obtained both from the subject and from her parents. No abnormal findings were reported.

Autoradiographic studies performed on cultured leucocytes from subjects with an $\mathrm{X}$ iso $\mathrm{X}$ chromosome complement show that it is invariably the isochromosome that is inactivated (Muldal et al., 1963). This apparent contradiction of the Lyon (I96I) hypothesis has been explained by Gartler and Sparkes (1963) by assuming that at some stage of early embryonic life the cells whose normal X chromosomes are inactivated will die, the survivors being those cells in which the isochromosome is inactivated. The final result, therefore, should be similar to those individuals having an XO chromosome composition, in which the single $\mathrm{X}$ chromosome is either inactivated, in which case the cell dies, or remains extended and genetically active, ensuing clones being normal.

There is some evidence (Reed, Simpson, and Chown, 1963) suggesting that in normal individuals inactivation of the $\mathrm{X}$ chromosome may not be complete, and it is of interest to speculate if inactivation of the isochromosome may be likewise incomplete.

Some authorities consider that abnormal mitosis may be produced by abnormal immunological mechanisms (Falikow, 1964). The finding of a high frequency of thyroid auto-antibodies (Engel, Forbes, Mantooth, and Socolow, 1963) in patients with the more usual form of ovarian dysgenesis (XO, and $\mathrm{XO} / \mathrm{XX}$ mosaics) supports this view. In patients having an $\mathrm{X}$ iso $\mathrm{X}$ chromosome complement, there is a high incidence of thyroiditis (Williams et al., I964; Sparkes and Motulsky, 1963). Although there is as yet no evidence of thyroiditis in the first patient reported in this communication, she does have a weak thyroglobulin antibody titre, though no thyroid auto-antibodies could be demonstrated in her parents' sera. In Hashimoto's thyroiditis there may be a normal ${ }^{131}$ I uptake, but PBI is often raised (Murray, 1964). This is due to (a) impaired iodine binding resulting in a release of unbound iodide from the thyroid cells, the socalled discharge phenomenon; (b) the leakage of abnormal, butanol insoluble, iodoproteins or iodopeptides directly into the circulation; and (c) a destructive reduction of the total thyroid iodine pool. The disorder usually becomes manifest in middle-aged women when hypothyroidism is associated with a rapidly enlarging goitre. Some cases of autoimmune thyroiditis remain euthyroid. It is of interest to note that the subject had a normal 131I uptake but a raised PBI. Her age was I5 years when these investigations were carried out compared with 23 and 24 years, respectively, in the subjects reported by Sparkes and Motulsky, an\& 34 and 31 years in the subjects described by: Williams et al.

Other workers suggested that abnormalities of the $\mathrm{X}$ chromosome were directly responsible for abnormal antibody formation. According to Burch (1963), cell bound antibody may be synthesized vi messenger RNA coded from an autosomal locus? and a locus on one $\mathrm{X}$ chromosome; the formets synthesizing the 'light' polypeptide, and the lattes the 'heavy' polypeptide chains. On theoretical grounds it was suggested (Burch and Rowell, 1963 that as well as somatic autosomal mutations, four mutant inherited genes on the $\mathrm{X}$ chromosome mas feature in the aetiology of Hashimoto's thyroiditisio If one assumes that either the isochromosome of the long arm of $\mathrm{X}$ is not completely inactivated, or that in stem cells of the lymphoid series inactivation does not occur, and that the isochromosome is isoallelic (i.e. the arms are genetically identical), it would be necessary to postulate the inheritance on only two mutant genes on one parental $\mathrm{X}$ chromo some before isochromosome formation during meiosis. If this were correct, and as yet there is noD experimental evidence, it may help to explain the. high incidence of active thyroiditis in subjects with an $\mathrm{X}$ iso $\mathrm{X}$ chromosome complement. It would also be necessary to postulate that the isochromm? some is not completely genetically inert.

Perhaps both theories are acceptable. A higlo circulating level of auto-antibodies may produces chromosomal abnormalities, but if by chance $a b \frac{\mathbb{Q}}{2}$ normalities of the $\mathrm{X}$ chromosome occur, abnormat antibody production may result. The study anfs follow-up of similar patients and their relatives mays shed more light on this problem.

\section{Summary}

Reports are given of 2 patients with gonadab dysgenesis due to presumed isochromosome forma 3 . tion of the long arm of $\mathrm{X}$. The clinical features agree with those described by previous authors $₹$ The association between abnormalities of the $X_{0}$ chromosome and antibody production is discussed

My thanks are due to Mrs. M. Bennett for heN permission to include the second case, and for hef constant encouragement; Dr. F. Lewis, Southmeads Hospital, Bristol, for the chromosomal and autoradiow graphic work; Dr. Ruth Sanger, M.R.C. Blood Group Research Unit, the Lister Institute, London, who reported on the $\mathrm{Xg}^{\mathrm{a}}$ blood groups; Professor $\mathrm{L}$. SO Penrose, the Galton Laboratory, University College $\bar{D}$ London, for the dermatoglyphic analysis; Dr. $\mathbf{R}_{+}$ Gibson, Area Central Laboratory, Bath, for the bio- 
chemical investigations; and Dr. G. Foss, United Bristol Hospitals for reading the manuscript and for many helpful suggestions.

The study was supported by a Grant from the Emily Showering Trust.

\section{REFERENCES}

Albright, F., Smith, P. H., and Fraser, R. (1942). A syndrome characterized by primary ovarian insufficiency and decreased stature. Report of I I cases with a digression on hormonal control of axillary and pubic hair. Amer. F. med. Sci., 204, 625.

Burch, P. R. J. 1963). Autoimmunity: some aetiological aspects. Lancet, $\mathrm{I}, 1253$.

- and Rowell, N. R. (1963). Autoimmunity. Aetiological aspects of chronic discoid and systemic lupus erythematosus, systemic sclerosis, and Hashimoto's thyroiditis. Some immunological implications. ibid., 2, 507.

Denver Classification (1960). A proposed standard system of nomenclature of human mitotic chromosomes. ibid., $1,1063$.

De la Chapelle, A. (1962). Cytogenetical and clinical observations in female gonadal dysgenesis. Acta endocr. (Kbh.), 40, Suppl. 65.

Engel, C., Forbes, A. P., Mantooth, L. C., and Socolow, E. L. (1963) Abstracts, Annual Meeting, American Society of Human Genetics, New York, July I8-21, p. 18.

Fialkow, P. J. (1964). Autoimmunity: a predisposing factor to chromosomal aberrations? Lancet, $1,474$.

Forbes, A. P., and Engel, E. (1963). The high incidence of diabetes mellitus in $4 \mathrm{I}$ patients with gonadal dysgenesis, and their close relatives. Metabolism, 12, 428 .

Gartler, S. M., and Sparkes, R. S. (1963). The Lyon-Beutler hypothesis and isochromosome $\mathrm{X}$ patients with the Turner syndrome. Lancet, $2,4 \mathrm{I}$ I.

Giannelli, F. (1963). The pattern of X-chromosome deoxyribonucleic acid synthesis in two women with abnormal sex-chromosome complements. ibid., $\mathbf{1 , 8 6 3 .}$
Hamerton, J. L., Jagiello, G. M., and Kirman, B. H. (1962). Sex chromosome abnormalities in a population of mentally defective children. Brit. med $\mathcal{F}$., $\mathbf{1}, 220$.

Jacobs, P., Harnden, D. G., Buckton, K. E., Court Brown, W. L., King, M. J., McBride, J. A., MacGregor, T. N., and Maclean, N. (I96I). Cytogenetic studies in primary amenorrhoea. Lancet, $1,1183$.

Lindsten, J. (1963). The Nature and Origin of X Chromosome Aberrations in Turner's Syndrome. A Cytogenetical and Clinical Study of 57 Patients. Almqvist and Wiksell, Stockholm.

, Fraccaro, M., Ikkos, D., Kaijser, K., Klinger, H. P., and Luft, R. (1963). Presumptive iso-chromosomes for the long arm of the $\mathrm{X}$ in man. Analysis of five families. Ann. hum. Genet., 26, 383 .

Lyon, M. F. (196I). Gene action in the X-chromosome of the mouse (Mus. musculus L.). Nature (Lond.), 190, 372.

Moorhead, P. S., Nowell, P. C., Mellman, W. J., Battipps, D. M. and Hungerford, D. A. (1960). Chromosome preparations of leukocytes cultured from human peripheral blood. Exp. Cell Res., 20, 613.

Muldal, S., Gilbert, C. W., Lajtha, L. G., Lindsten, J., Rowley, J., and Fraccaro, $M$. (1963). Tritiated thymidine incorporation in an isochromosome for the long arm of the $\mathrm{X}$ chromosome in man. Lancet, $\mathrm{x}, 86 \mathrm{r}$.

Murray, I. P. C. (1964). Thyroid Disorders; A Guide to Diagnosis and Treatment. Pitman, London.

Polani, P. E. (196r). Turner's syndrome and allied conditions. Brit. med. Bull., 17, 200.

Reed, T. E., Simpson, N. E., and Chown, B. (1963). The Lyon hypothesis. Lancet, 2, 467.

Sparkes, R. S., and Motulsky, A. G. (1963). Hashimoto's disease in Turner's syndrome with isochromosome X. ibid., $1,947$.

Turner, H. H. (1938). A syndrome of infantilism, congenital webbed neck, and cubitus valgus. Endocrinology, 23, 566.

Williams, E. D., Engel, E., and Forbes, A. P. (1964). Thyroiditis and gonadal dysgenesis. Nerw Engl. F. Med., 270, 805. 